\title{
Mechanisms of Weak Governance in Grasslands and Wetlands of South America
}

\author{
Luca Eufemia $1,2, *\left(\mathbb{0}\right.$, Michelle Bonatti ${ }^{1,2}$, Stefan Sieber ${ }^{1,2}$, Barbara Schröter ${ }^{1}(\mathbb{D}$ \\ and Marcos A. Lana ${ }^{3}$ \\ 1 Sustainable Land Use in Developing Countries (SusLAND), Leibniz Centre for Agricultural Landscape \\ Research (ZALF), Eberswalder Straße 84, 15374 Müncheberg, Germany; Michelle.Bonatti@zalf.de (M.B.); \\ stefan.sieber@zalf.de (S.S.); barbara.schroeter@zalf.de (B.S.) \\ 2 Department of Agricultural Sciences, Humboldt University of Berlin (HU), Invalidenstraße 42, \\ 10099 Berlin, Germany \\ 3 Department of Crop Production Ecology, Swedish University of Agricultural Sciences (SLU), Almas Allé 8, \\ 75007 Uppsala, Sweden; marcos.lana@slu.se \\ * Correspondence: luca.eufemia@zalf.de; Tel.: +49-33432-82-221
}

Received: 16 August 2020; Accepted: 1 September 2020; Published: 3 September 2020

check for updates

\begin{abstract}
Weak governance is a major threat to sustainable development, especially in rural contexts and within ecosystems of great social and economic value. To understand and compare its arrangement in the grasslands and wetlands of the Colombian Llanos and the Paraguayan Pantanal, we build upon the Institutional and Development Framework (IAD) as we explore the role of political, economic, and social institutions and combine components of the theory of common-pool resources (CPR) and new institutional economics (NIE). This hybrid conceptualization provides a synthesis of how top-down hierarchical and market-based systems of community-based and natural resource management negatively affect sustainable development in both study areas. Our findings suggest three underlying mechanisms causing a situation of weak governance: centralized (economic and political) power, the role of central and local governments, and social exclusion. Understanding these multidimensional contextual mechanisms improves the understanding that institutional structures supporting arrangements that handle grasslands and wetlands in a sustainable way are needed to protect the ecosystem's social and economic values, especially in rural and marginalized contexts.
\end{abstract}

Keywords: Colombia; common-pool resources; Orinoquia; Llanos Orientales; Pantanal; Paraguay

\section{Introduction}

Because grasslands and wetlands cover approximately half of the world's ice-free land area, comprising about $70 \%$ of the world's agricultural and livestock area, these are important agricultural resources, especially in areas where people lack food security [1]. Biodiversity and ecosystem services in grasslands and wetlands are degrading faster than ever before in human history $[2,3]$. These ecosystems are at the center of socio-economic conflicts in areas with extensive rural poverty and where people and economies are highly dependent on natural resources. In South America, grassland and wetland ecosystems cover 269 million ha [4]. Most (76\%) belong to the Cerrados of Brazil, but about $11 \%$ (28 million ha) form the Venezuelan Llanos and 6\% (16-17 million ha) the Llanos Orientales of Colombia [4,5]. These last areas are seen as a single ecoregion, the Llanos of the Orinoquia. The remaining $7 \%$ is the mosaic of flooded grasslands, savannas, and tropical forests forming the Pantanal, the world's largest wetland, stretching across Bolivia, Brazil, and Paraguay [6]. This wetland area is part of a larger dry plain of around 100 million ha, known as the Gran Chaco. The Gran Chaco Americano is increasingly used for livestock grazing and raising crops, with the conversion of natural vegetation accelerating. Approximately 500 ha per day are deforested in the Paraguayan part of the Gran Chaco Americano [7]. 
These grasslands and wetlands play a crucial role in sustainability issues, with social-cultural, economic, and environmental values. Beyond providing habitat for plants and animals that are adapted to the unique hydrologic regimes and soil conditions [8,9], they provide important ecosystem services, including climate regulation and water purification [10-12]. Local communities and indigenous peoples provide cultural values, embodied in their knowledge about nature conservation and the sustainability of traditional subsistence systems [13,14].

Although literature on these valuations exist [9,15-19], interdisciplinary and socio-economic approaches, especially those including discourses on governance in developing countries, are scarce. Hence, grasslands represent the least understood biome in terms of their true value for sustainable economic uses and their contribution to human health and well-being through sociocultural services [20,21]. Better understanding social dynamics, including indigenous and traditional values, requires science-based valuations to leverage narratives on the region's sustainable development [22-26]. De facto, interdisciplinary research incorporating socio-economic approaches as important determinants of value is critical for policy making [12,18,26-28].

Regarding our Colombian and Paraguayan cases, only a tiny percentage of the Colombian Llanos (in the districts of Yopal and Paz de Ariporo) and Paraguayan Pantanal (in the municipality of Bahía Negra) benefit from legal protection; most land is converted for intensive usage [29-31]. Increasing demand for agricultural commodities drives the conversion of Latin American grasslands and wetlands, including our case study areas, into cropland, with significant consequences for the environment, local communities, and democracy [30-32]. In both Colombia and Paraguay, the expansion of agroindustry, extensive overgrazing, cattle ranching, insecurity of land tenure, unsustainable infrastructure development, and weak enforcement of environmental laws are the main threats to culture and biodiversity conservation $[29,33,34]$.

The historical distribution of land and the roots of both eco-regions are starkly reflected in existing antagonisms between peasants and those elites who control the land: great land owners in Paraguay and guerrilla and paramilitary groups in Colombia [35-40]. Grasslands and wetlands are unique sites receiving increasing attention from leading environmental and human rights organizations (e.g., The German Agency for International Cooperation (GIZ), World Wildlife Fund (WWF), Amnesty International, etc.). However, for Paraguay, there is a significant gap in the governance research literature, especially at the community level $[28,29,41]$. We draw on the literature regarding participatory and environmental governance approaches for wetlands in the region $[28,42,43]$. For Colombia, although several analyses (e.g., policy papers) concentrate on land use, biodiversity, and renewable energy $[2,34,44]$, literature analyzing community-based governance models is lacking. Our contribution tries to fill this gap by investigating local perceptions about economic and political centralization, the role of governments, and social exclusion. We follow existing literature, discussing weak governance, which is understood as a widespread system of corruption and unlawful behavior, and how it contributes to increasing negative consequences, including environmental, socio-economic, and institutional conflicts, along with social exclusion and poverty [12,26-29].

According to Vatn (2010), three governance structures exist: hierarchies, markets, and community management [45]. Community-based governance models offer valid tools to resolve conflicts over a number of issues, including natural resource use and management [46,47]. It also helps empower a community-based environment, where inclusion and engagement are key factors [48]. In South America, as a concrete means to promote social and economic welfare, as well as land-ownership rights and conservation issues, participatory community-based governance is being tested through a number of voluntary actions including cooperatives, syndicates, and associations [23-25,43,49,50]. This trend often results in resistance to centralized, top-down model structures, whether political, institutional, or economic; those only represent the wealthiest elites. Modern governance discourse "signals a weakening of the state-centric view of power and societal steering that has been problematized by recent empirical and ideological developments" [51] (pp. 2-4). Post-modern decentring of power is a key issue in developing countries [52]. Governmental processes concerning South American grasslands and 
wetlands must address socio-economic and environmental changes, power and hierarchical structure at all scales, and political dynamics, as well as stakeholder engagement schemes [5,28,29,33,44,52-57]. To this end, our focus is on marginalized rural communities because of their vulnerability to weak governance, as they lack human, political, and financial capacity to protect their rights over land and natural resource use and management [58]. In this context, our research question seeks to investigate mechanisms of weak governance and how they are structured in the Colombian Llanos and Paraguayan Pantanal.

\section{The Umbrella Framework}

To contribute to the literature and guide our research, we develop our work under the umbrella of the Institutional Analysis and Development Framework (IAD). IAD is widely employed in research on community-based management of natural and common resources [59-63]. Because institutions are the main prescription for repetitive and structured interactions in governance and self-government environments [60], IAD helps identify key factors for institutional and participatory aspects [63]. It adds the systematic analysis of collective action in relation to the use and management of natural resources, focusing on institutions. IAD's core is the "action arena", comprising the social spaces where actors interact (the actual situation) and the actors themselves (participants) [64,65]. The "exogenous variables", those influencing the action arena, are useful for defining the context (e.g., to understand what might happen in the action arena), including community attributes, physical attributes, and the rules in use [66]. Within our research, we adapt the IAD to the needs and criteria of the two main theoretical frames addressed here: the theory of common-pool resources (CPR) and new institutional economics (NIE). Both theories seek to analyze institutions, whether political, economic, formal, or informal, as well as the possible overlaps, aiming to contribute to economic and social development.

The first theory offers much empirical data and a solid frame [64,66-70], because scholars are increasingly studying the governing of natural resources by a community or a number of individuals. CPR helps us understand the role of communities and their relations with ecosystems. A simple assumption of a successful CPR model is to maintain a common resource for an extended time without outside intervention [67]. Hence, the possibility of overexploitation is resolved when there is an 'increase in the capacities of participants to change coercive rules of the entire game' [71] (pp. 263-277). Similarly, as claimed by Saunders (2014), 'CPR theory tends to conceptualise heterogeneous communities as autonomous "rational resource users" with fixed identities and a common purpose' [70] (pp. 649-666). This is how we address the theory of CPR: over time, societies develop institutional mechanisms, whether formal or informal, whether legal or rooted in tradition, and customs that efficiently and successfully manage natural resources.

The second theory reflects an economic approach that is relevant in the rules (or institutions) of participants when they are interdependent. Most studies regard the theory of institutional economics [72-75] as a step beyond neoclassical economics because it studies the structure of property rights. As reinforced by Ollila (2009), this theoretical approach,

"Analyses whose costs are taken into account in the economic calculus and what market measures can be considered as efficient outcomes. For example, what is the relation between efficiency and social acceptance? The market may produce multiple "efficient" outcomes and, thus, one must decide what kind of a state of a market is preferable." [76] (pp. 21-26)

Therefore, efficiency is determined by the institutional set (property rights). A further development of this concept is new institutional economics (NIE), which focuses on the role that culture, legal systems, political institutions, and other instances have on economic development. Yet, the meaning of institutions remains as "the rules of the game" while actors are the "players of the game". As Alston et al. (1996) and North (2005) conceptualize, institutions are informal rules and limitations (sanctions, taboos, customs, traditions, and codes of conduct), as well as formal rules (constitutions, laws, property 
rights) $[77,78]$. Thus, within the lens of economic and social development, mechanisms underlying weak governance are explained, classified, and analyzed using NIE.

\section{Methodology}

\subsection{Case Study Descriptions}

Due to the aforementioned socio-ecological similarities, we focus on the Department of Casanare in the Colombian Llanos (in the districts of Yopal and Paz de Ariporo) and the Department of Alto Paraguay in the Paraguayan Pantanal (in the municipality of Bahía Negra) (Figure 1). Agricultural production is the principle threat to the savannahs and grasslands in both areas, while land use and management rarely includes ecological and social criteria that safeguard natural ecosystems, biodiversity, and carbon stocks. Land use and the ongoing transformation of natural ecosystems negatively affect local and community-based governance structures.

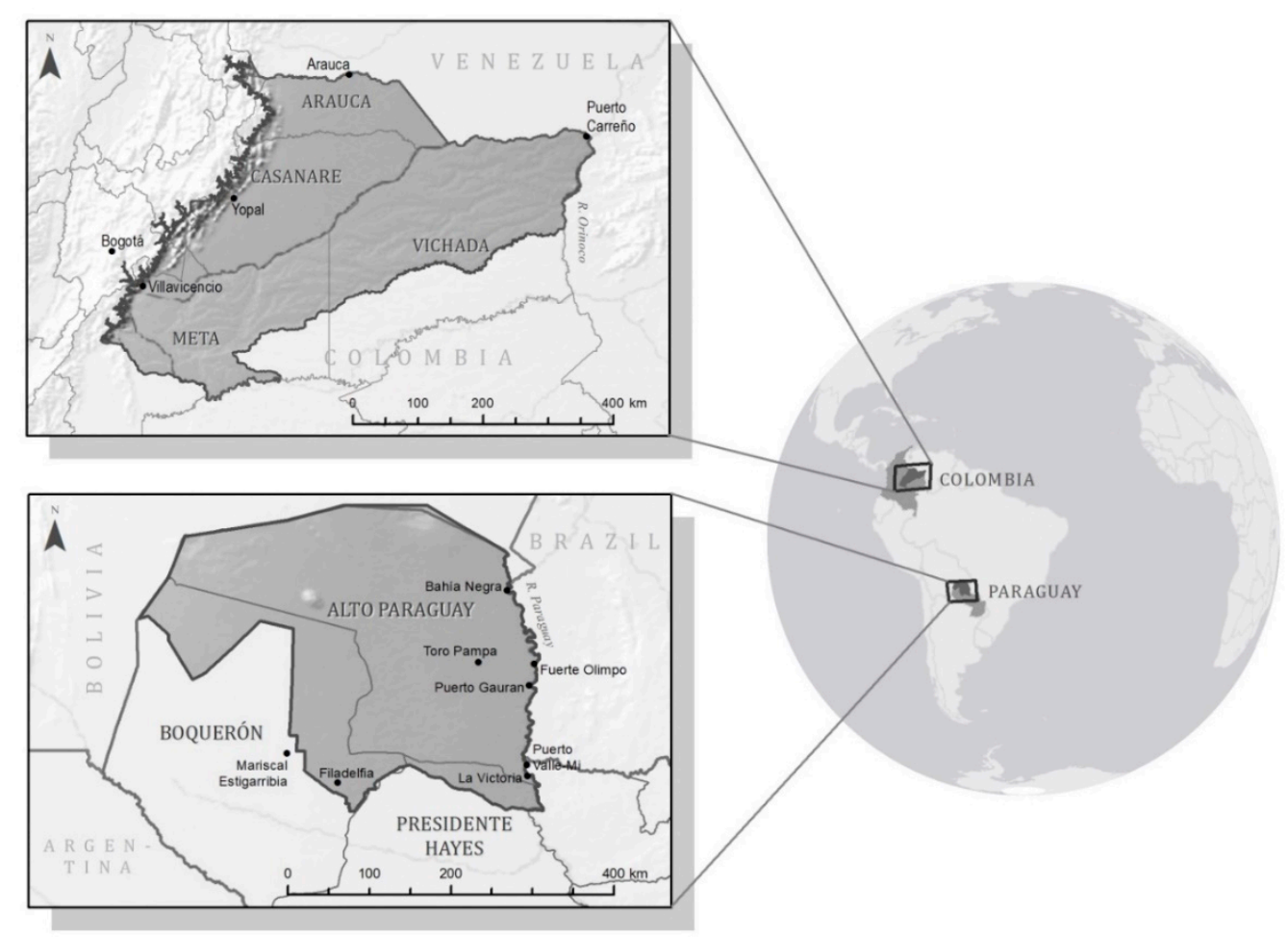

Figure 1. Base-map Service Layer Credits: Esri, HERE, DeLorme, MapmyIndia (C, OpenStreeMap contributors and the GIS User Community.

\subsection{Methodological Procedures}

We use a mixed methods approach across three methodological phases: (A) exploratory research including an international literature review and non-structured interviews with 10 key informants; (B) field-based studies consisting of an online survey of 32 regional experts; and (C) a set of semi-structured interviews based on the Governance Analytical Framework (GAF) [79], involving 102 local participants. Figure 2 displays the three steps of the procedure. Data were gathered from 144 people, including informants, regional experts, and local participants. The entire methodology draws upon the IAD framework, including contextual perspectives (attributes of community, attributes of physical world rules-in-use) throughout Phases A, B, and C. Figure 3 shows the adapted IAD framework. 


\section{Methodological procedures}

Three-step analysis

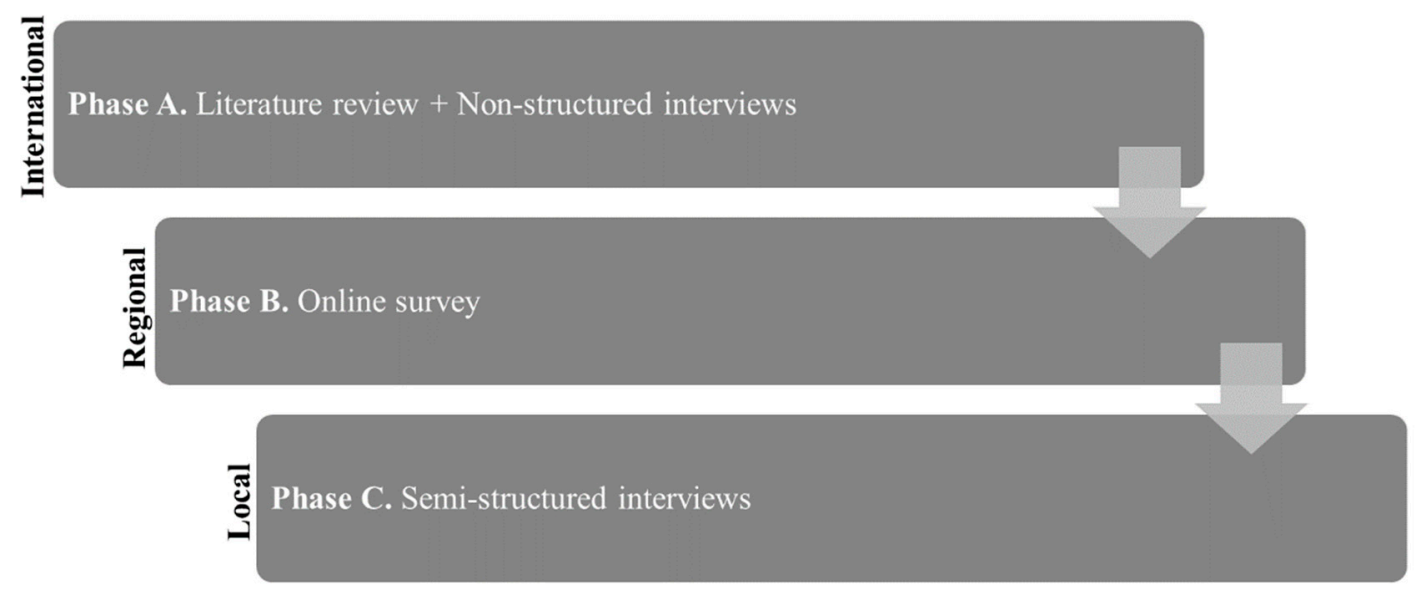

Figure 2. Methodological procedures-Three-step analysis.

\section{Adapted IAD framework for Methodological procedures}

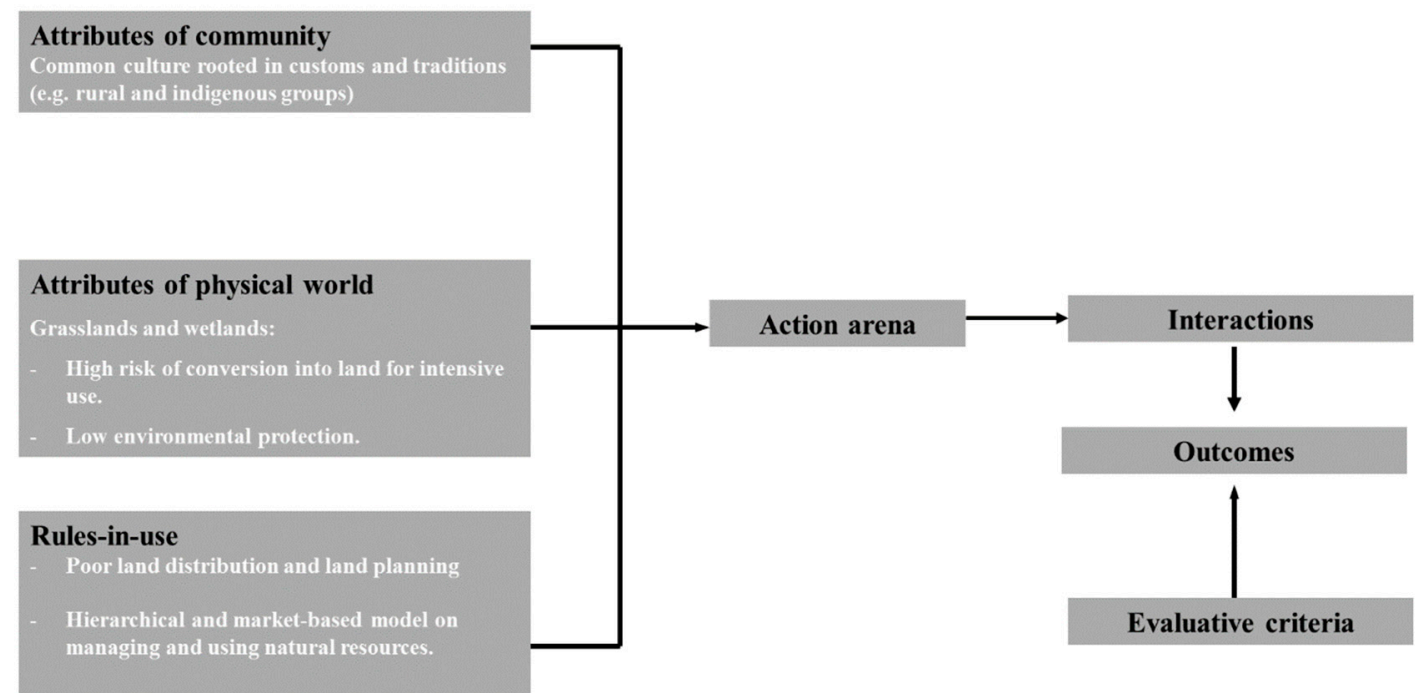

Figure 3. Adapted Institutional and Development (IAD) framework for Methodological procedures. Source: [63].

During Phase A, we reviewed the international literature on the governance, participatory approaches, and socio-economics of grasslands and wetlands. The screening of science-based knowledge used online databases (e.g., Science Direct, Google Scholar, etc.) and national archives in both English and Spanish, including studies from the 1970s to early 2019. Keywords used included grasslands, governance, South America, and community-based governance. Case studies on wetlands and grasslands were found by interviewing 10 key informants identified through networking and inter-institutional connections (see Appendix A). The non-structured interviews focused on two specific case-studies, one in Colombia and one in Paraguay.

In Phase B, we conducted an online survey (http://soscisurvey.de/), targeting experts from well-established organizations in Colombia and Paraguay. From an initial pool of informants, we employed snowball sampling, identifying potential participants who met the eligibility criteria [80]. We engaged with organizations based on their expertise with social, economic, political, 
and environmental issues in the case study areas (see Appendix A). Criteria for the Phase B study-sample comprised: presence (e.g., minimum 5 years) of work in the areas of study; professional career (e.g., working position/responsibilities) and relevance to the areas of study; and educational degree (e.g., undergraduate/post-graduate). In total, 45 experts were identified, of which 32 responded to the survey. The sample comprised diverse actors and knowledge areas, covering the complexity of our research problem. Participants belonged to academia (e.g., national universities), civil society (e.g., NGOs (Non-governmental organizations), associations etc.), the private sector (e.g., private companies present in the areas), and the public sector (central, regional, and local institutions).

We created sub-categories corresponding to the characteristics and indicators for each category, presented in Table 1. Questions for experts related to four topics: (1) the use and management of natural resources and their relation to land distribution; (2) the presence of Ostrom's eight principles of managing common-pool resources and their relation with present formal and informal boundaries reflecting the perceived power relations [56]; (3) conjectures related to a diverse range of forms of institutions in the areas of study; and (4) existing models of community-based sustainability within the agenda of economic models. Under Topic 1, we offered a list of potential threats to the specific ecoregion (e.g., misuse of natural resources, over-exploitation, global warming, population growth, urbanization, etc.), asking experts to pick one option. Topic 2 comprised tick boxes with yes/no options for each of Ostrom's eight principles. We also added four open questions about rules (both formal and informal), decision making processes, law implementation, and the current status of information and education about natural resources. Under Topic 3, we added two lists of questions. In the first, experts picked one main possible constraint for governing natural resources from a list (e.g., corruption, impunity, centralized natural resource management, lack of human and financial capacity of local governments, etc.). For the second, experts were asked to pick the two most relevant social interactions in the regions (e.g., economic exchange, voter-politician relations, inter-ethnic conflicts, and/or cooperation, etc.). Topic 4 comprised a single tick box (yes/no) about existing cases of communities managing natural resources. If the answer was yes, they were asked to choose an economic model (either top-down or bottom-up). If no, there were four open questions about social relations (e.g., corporations/social marginalization, social welfare/sustainable development, local interests/national and local scales, intra-sectorial relations/conflicts, gender equality/social exclusion) that sought relevant considerations. In Phase B, we designed and implemented a questionnaire of 45 questions, using the sections of characteristic and indicators (Table 1). From the online questionnaire, we extracted percentages for each characteristic and indicator to determine the most relevant perceptions of the local experts.

Phase $C$ is based on the Governance Analytical Framework (GAF) [79]. This tool allows us to systematize our field work analysis. With its broad adaptability and applicability on the ground, GAF allows researchers to describe socio-ecological processes within specific and unique contexts [81-83]. GAF focuses on social interactions within which actors/participants make decisions regarding a collective problem, thereby creating and reinforcing social norms or institutions [79]. It comprises five analytical tools: problems, actors, social norms, processes, and nodal points. Field study constraints limited us to focusing on two: problems and social norms (Figure 4). The category actors were initially covered by a stakeholder identification and mapping based on the analysis for this research. Time constraints for our field study prevented us from developing an analysis of processes and nodal points. The GAF survey was clustered in two blocks: questions to understand perceived shared problems, a condition to be improved upon (collective problems); and questions highlighting the perceived institutions or practices to preserve (social norms). Both sets of questions were formulated as lists, thus providing respondents the opportunity to rank suggested categories from most to least relevant.

In the Colombian Department of Casanare (the districts of Yopal and Paz de Ariporo), we interviewed 50 individual respondents, representing 17 groups, including civil society (9 groups), the public sector (5 groups), and the private sector (3 groups). Each interview was authorized and transcribed, lasting between one and three hours. In Paraguay, we analyzed the municipality of Bahía 
Negra in the Department of Alto Paraguay, interviewing 52 people, representing 15 groups across three societal sectors: the public sector (3 groups), the private sector (5 groups), and civil society ( 7 groups) (see Appendix A). A field diary recorded qualitative data and notes on the behaviors and interactions of all actors involved in this study $[84,85]$.

Table 1. Characteristic and indicators of common-pool resources (CPR) and the new institutional economics (NIE) in the context of the four topics $(1,2,3,4)$.

\begin{tabular}{ll}
\hline \multicolumn{1}{c}{ CPR } & NIE \\
\hline \multicolumn{2}{c}{ 1. Use and management of natural resources } \\
$\begin{array}{ll}\text { If and how, experts address issues about managing } \\
\text { grasslands, wetlands, and forests. }\end{array}$ & $\begin{array}{l}\text { Roots and significance of land distribution (property } \\
\text { rights) according to experts' perception (updated data } \\
\text { from official sources is missing). }\end{array}$ \\
\hline
\end{tabular}

$$
\text { 2. Common pool resources }
$$

If, and how, local and rural communities respond to Ostrom's eight principles for managing Commons:

1. Define clear group boundaries (effective exclusion of external unentitled parties).

Expert's perception of institutions and power relations in the area (hierarchy):

2. Match rules governing use of common goods to local needs and conditions.

3. Ensure that those affected by the rules can participate in modifying the rules.

4. Make sure the rule-making rights of community members are respected by outside authorities.

- Informal boundaries (sanctions, taboos, customs, traditions, and codes of conduct)

5. Develop a system, carried out by community members, for monitoring members' behavior.

6. Use graduated sanctions for rule violators.

7. Provide accessible, low-cost means for dispute resolution.

- Formal boundaries (constitutions, laws, property rights).

8. Build responsibility for governing the common resource in nested tiers from the lowest level up to the entire interconnected system.

\section{Institutions}

Formal/informal/legal/illegal institutions managing natural resources.

\begin{tabular}{ll}
\hline & 4. Cases \\
\hline $\begin{array}{l}\text { Specific cases of communities managing natural } \\
\text { resources directly and in which forms. }\end{array}$ & $\begin{array}{l}\text { Economic models (export-market asset) in relation to } \\
\text { community-based rules: }\end{array}$ \\
\cline { 2 - 2 } & $1 . \quad$ Given top-down from central governmental bodies. \\
\cline { 2 - 2 } & $2 . \quad$ Created locally (formal/informal settings). \\
\hline
\end{tabular}




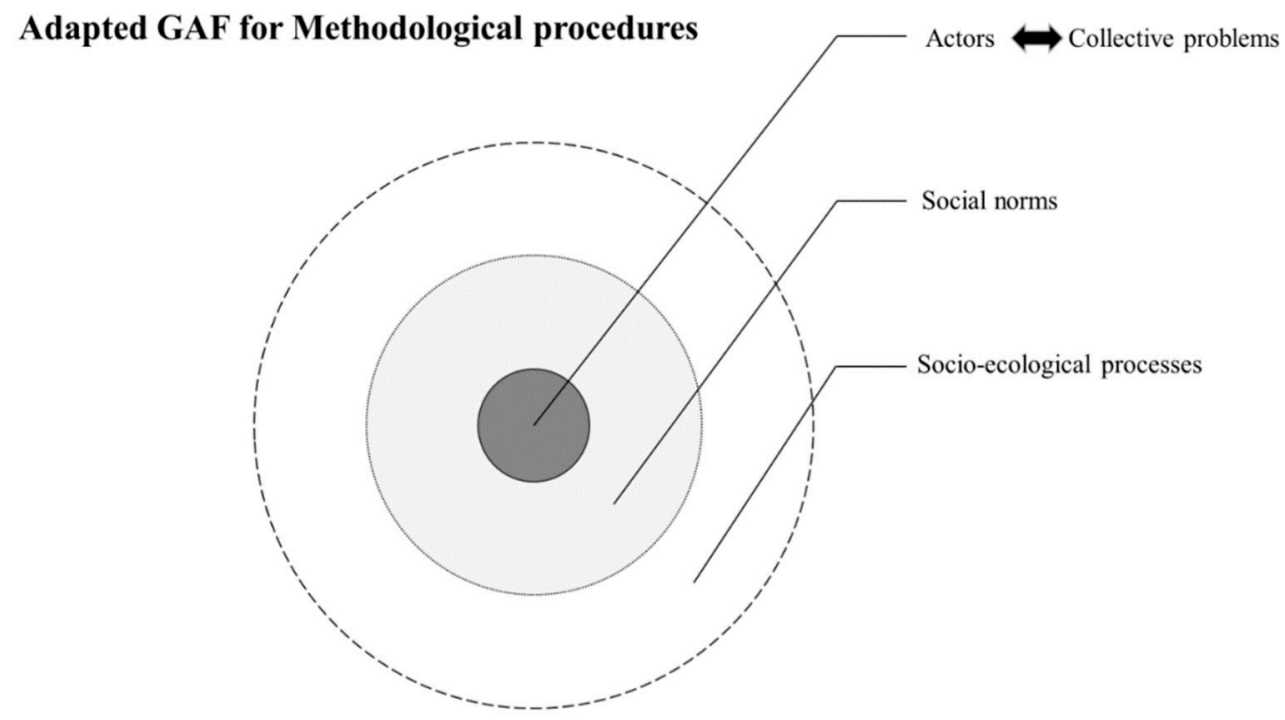

Figure 4. Adapted Governance Analytical Framework (GAF) for Methodological procedures. Source: [81].

\section{Results}

The results follow the same structure of the two main methodological Phases (B and C) for each case study. Results of Phase A served to develop a better contextual understanding. A total of 144 people (informants, experts, and participants), representing many institutions, participated.

\subsection{Colombian Llanos}

\subsubsection{Online Survey in Colombia (Phase B)}

Fifteen experts from Colombia responded fully to the online questionnaire (Phase B). The respondents were diverse: $40 \%$ from academia, $26 \%$ public sector, $26 \%$ non-governmental organizations, and $8 \%$ the private sector. Figure 5 summarizes relevant findings in percentages and corresponding number of persons, based on local expert perceptions. 


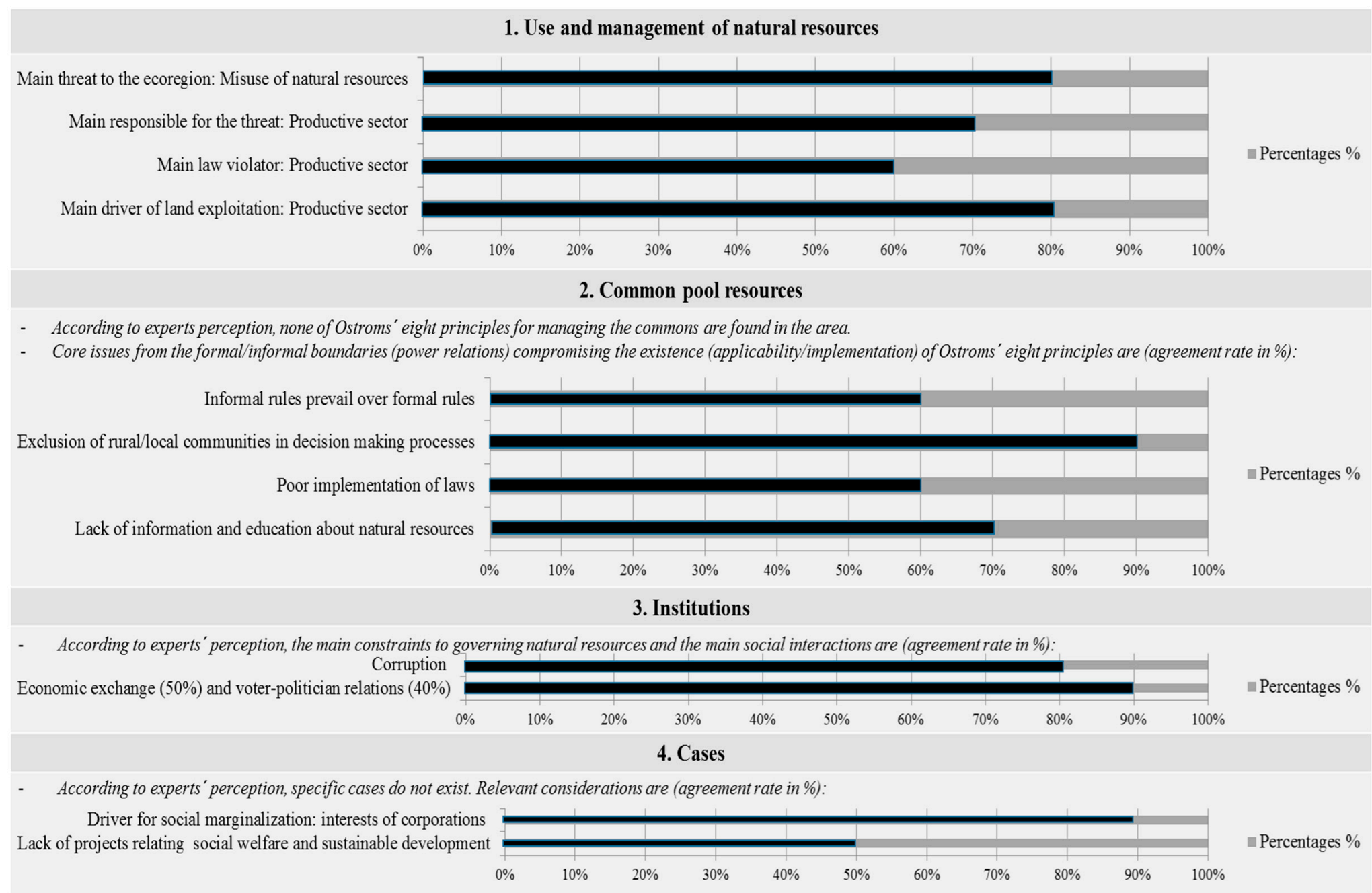

Figure 5. Colombia—Results of characteristic and indicators of common-pool resources (CPR) and the new institutional economics (NIE) in the context of the four topics $(1,2,3,4)$. 
Regarding the use and management of natural resources in comparison to land distribution (Topic 1 in Figure 5), more than 80\% of experts (12) perceive that the misuse of natural resources, understood as excessive and destructive use, is the most relevant threat in the Colombian region of the Llanos Orientales. For $70 \%$ of respondents, the productive sector is seen as the most detached from sustainably using natural resources, because its main priorities are intensifying productivity and generating profits. Productive sector stakeholders are not only perceived as the main law violators (60\%, 9 experts), in terms of non-compliance with current environmental laws, but also as the main drivers of land exploitation, including deforestation ( $80 \%, 12$ experts).

For common pool resources and the role of hierarchy (Topic 2 in Table 1), none of Ostrom's eight principles for managing resources are observed. Respondents report a lack of inclusive and effective community-based governance models. Four core issues regarding formal/informal boundaries (power relations) compromise the existence (applicability/implementation) of Ostrom's eight principles. The first is that $60 \%$ of experts (9) agree that informal rules (sanctions, taboos, customs, traditions, and codes of conduct) prevail over formal rules (constitutions, laws, property rights). Secondly, the remoteness of the region and the lack of decentralization of powers, particularly in relation to natural resource management and use, mean that local and rural communities are excluded from decision making processes; a claim supported by $90 \%$ of experts (13). The third factor, with $60 \%$ of experts agreeing (9), is poor implementation of laws, mostly due to weak local institutions (e.g., law enforcement). Finally, 70\% of experts (10) agree that the lack of information and education about the sustainable use and management of natural resources is an informal boundary constraining ecological alternatives.

Institutional perceptions (Table 1, Topic 3) suggest that corruption is the most relevant issue with regard to social inclusion in the use and management of natural resources; with $80 \%$ of experts (12) agreeing. Additionally, main social interactions are represented by economic exchange (50\%, 7 experts) and by voter-politician relations ( $40 \%, 6$ experts). With regard to the role of existing community-based governance models (Topic 4 in Table 1), experts could not identify any specific cases of local and rural communities managing natural resources. Yet, they raised two important considerations. First, $90 \%$ of experts (13) agree that the interests of agro-industrial and extractives companies are major drivers of social instability and marginalization. Second, 50\% of experts (7) agree that the lack of projects relating to social welfare and sustainable development is a limitation for the future development of community-based governance models.

\subsubsection{GAF Colombia (Phase C)}

GAF survey results are presented in Figure 6. Extractive activities, such as exploiting hydrocarbons (especially oil) and monoculture expansions (specifically, rice) are the two highest ranked collective problems, as perceived by the respondents. The critical importance of traditional livestock is represented as the main social norm in the region. Additionally, Community Action Boards (CAB) are ranked as an important social norm affecting community conduct. $\mathbf{C A B}$ are voluntary and participatory schemes of legal-norm-related action where communities can discuss and find solutions to collective problems. Not only are they civic and non-profit mechanisms, they are also community based organizations for social management. 


\section{Results of the GAF (Colombia)}

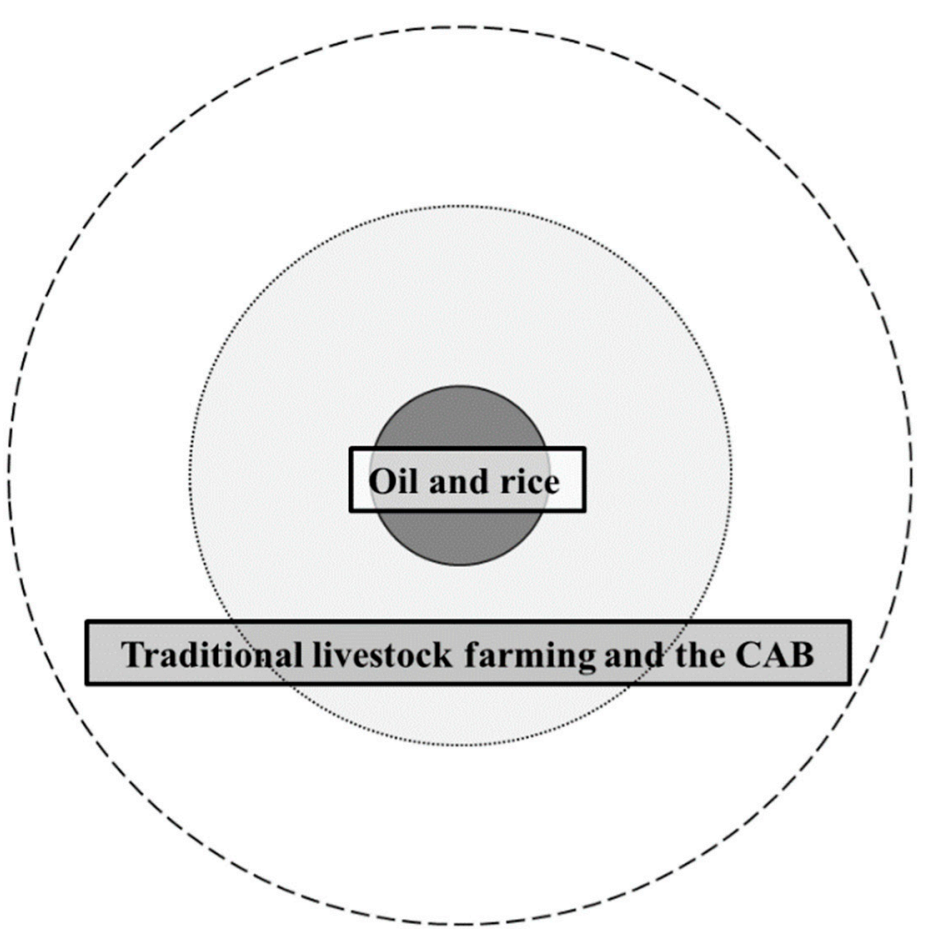

\begin{tabular}{|c|c|c|}
\hline Actors & Collective problems & Social norms \\
\hline $\begin{array}{l}\text { Public } \\
\text { Sector }\end{array}$ & $\begin{array}{r}\text { Oil } 27 \% \\
\text { Rice 20\% } \\
\text { Uncontrolled fires 14\% } \\
\text { The shift in cultural values 13\% } \\
\text { Illegal immigration } 12 \% \\
\text { Drug abuse } 7 \% \\
\text { Prostitution } 7 \%\end{array}$ & $\begin{array}{r}\text { Traditional livestock farming } 41 \% \\
\text { Eco-tourism } 39 \% \\
\text { Community Action Boards (CAB) } 20 \%\end{array}$ \\
\hline $\begin{array}{l}\text { Private } \\
\text { Sector }\end{array}$ & $\begin{array}{r}\text { Oil } 25 \% \\
\text { Rice } 25 \% \\
\text { Lack of environmental knowledge 13\% } \\
\text { Uncontrolled fires } 13 \% \\
\text { Lack of infrastructure } 14 \% \\
\text { The political situation } 10 \%\end{array}$ & $\begin{array}{r}\text { Certification schemes (livestock-farming) } 60 \% \\
\text { Grassland farming on native pasture } 23 \% \\
\text { Eco-tourism } 17 \%\end{array}$ \\
\hline $\begin{array}{l}\text { Civil } \\
\text { Society }\end{array}$ & $\begin{array}{r}\text { Rice } 22 \% \\
\text { Infrastructure } 22 \% \\
\text { Oil } 19 \% \\
\text { Unsustainable livestock farming } 11 \% \\
\text { Uncontrolled fries } 7 \% \\
\text { The shift in cultural values } 7 \% \\
\text { Oil palm plantations } 4 \% \\
\text { The political situation } 4 \% \\
\text { Hydrocarbon (other than oil) } 4 \%\end{array}$ & $\begin{array}{r}\text { Community Action Boards (CAB) } 52 \% \\
\text { Traditional livestock farming } 26 \% \\
\text { Subsistence agriculture } 22 \%\end{array}$ \\
\hline
\end{tabular}

Figure 6. Colombia—Results of the GAF (ranking). Source: [81]. 


\subsection{Paraguayan Pantanal}

\subsubsection{Online Survey in Paraguay (Phase B)}

Seventeen Paraguayan experts completed the online questionnaire, representing the public sector $(35 \%)$, NGOs $(35 \%), 18 \%$ academia $(18 \%)$, the private sector $(6 \%)$, and the media $(6 \%)$. Figure 7 summarizes the relevant findings, in percentages and corresponding number of persons, based on the perceptions of local experts.

Expert perception of land use and management of natural resources (Topic 1 in Figure 7) shows that over-exploitation of natural resources in the Paraguayan Pantanal is the main threat to the ecosystem $(80 \%, 13+)$. Both private and public sectors are responsible (40\% of agreement rate, $6+$ experts). The legacy of Paraguayan history, specifically Stroessner's dictatorship (1954 to 1989), still affects land-reparation and land-distribution issues, among other things. Moreover, not only do experts regard the private sector as the main law violator in the region, but also as the main driver of natural resource exploitation ( $50 \%$ and $50 \%$ agreement rate, 8 and 8 experts, respectively).

With respect to common pool resources and the role of hierarchy (Topic 2 in Figure 7), experts could not relate any of Ostrom's principles to present experiences or cases on the ground. However, important considerations were raised and agreed upon. For instance, $60 \%$ of experts (10) agreed that informal rules (sanctions, taboos, customs, traditions, and codes of conduct) prevail over formal rules (constitutions, laws, property rights). Further, $80 \%$ of experts $(13+)$ agreed that the region's remoteness and a lack of power decentralization, mainly in relation to natural resource management and use, mean that local and rural communities are excluded from decision making processes. An additional issue is the poor implementation of laws, mostly due to weak institutions (e.g., law enforcement) at the local level; something that $60 \%$ of experts (10) agreed upon. Lastly, $80 \%$ of experts (13+) agreed that the lack of information and education about the sustainable use and management of natural resources is an informal boundary constraining ecological alternatives.

Regarding institutional perceptions in the area (Figure 7, Topic 3), more than $70 \%$ of the experts (11+) found that impunity, understood as exemption from punishment or fines, is a central rule-of-the-game. Consequently, the two most perceived social interactions are economic exchange and voter-politician relations; with experts agreeing $60 \%$ (10) and $20 \%$ (3) of the time, respectively. Regarding existing practices of community-based governance models (Topic 4 in Figure 7), experts did not find any cases of local and rural communities managing natural resources. Nevertheless, they raised and agreed on two pertinent reflections. First, half the experts agreed that representation of local and indigenous interests at all scales, from the local to international, is low. Second, $90 \%$ of experts (15) agreed that intra-sectorial conflicts also emerge from the lack of participatory and community-based governance models.

\subsubsection{GAF Paraguay (Phase C)}

GAF survey results for Paraguay are presented in Figure 8. Land-grabbing, locally understood as a contentious issue surrounding large-scale land acquisition/speculation, is perceived as the main collective problem. Social norms show that sectorial representation and inclusion (in the forms of community roundtables and indigenous association) are two key factors through which problems are addressed and actions taken. 


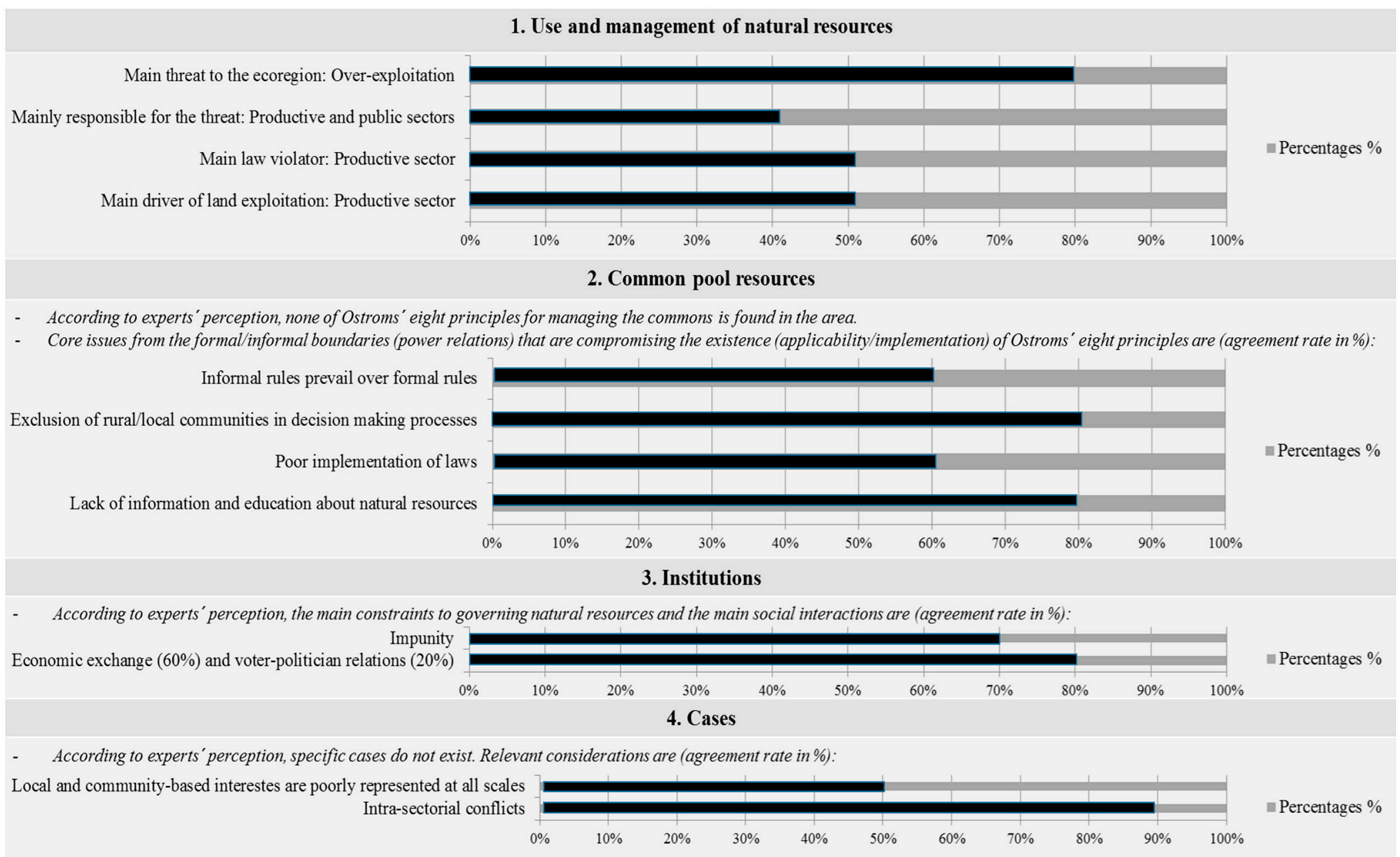

Figure 7. Paraguay—Results of characteristic and indicators of common-pool resources (CPR) and the new institutional economics (NIE) in the context of the four topics $(1,2,3,4)$. 


\section{Results of the GAF (Paraguay)}

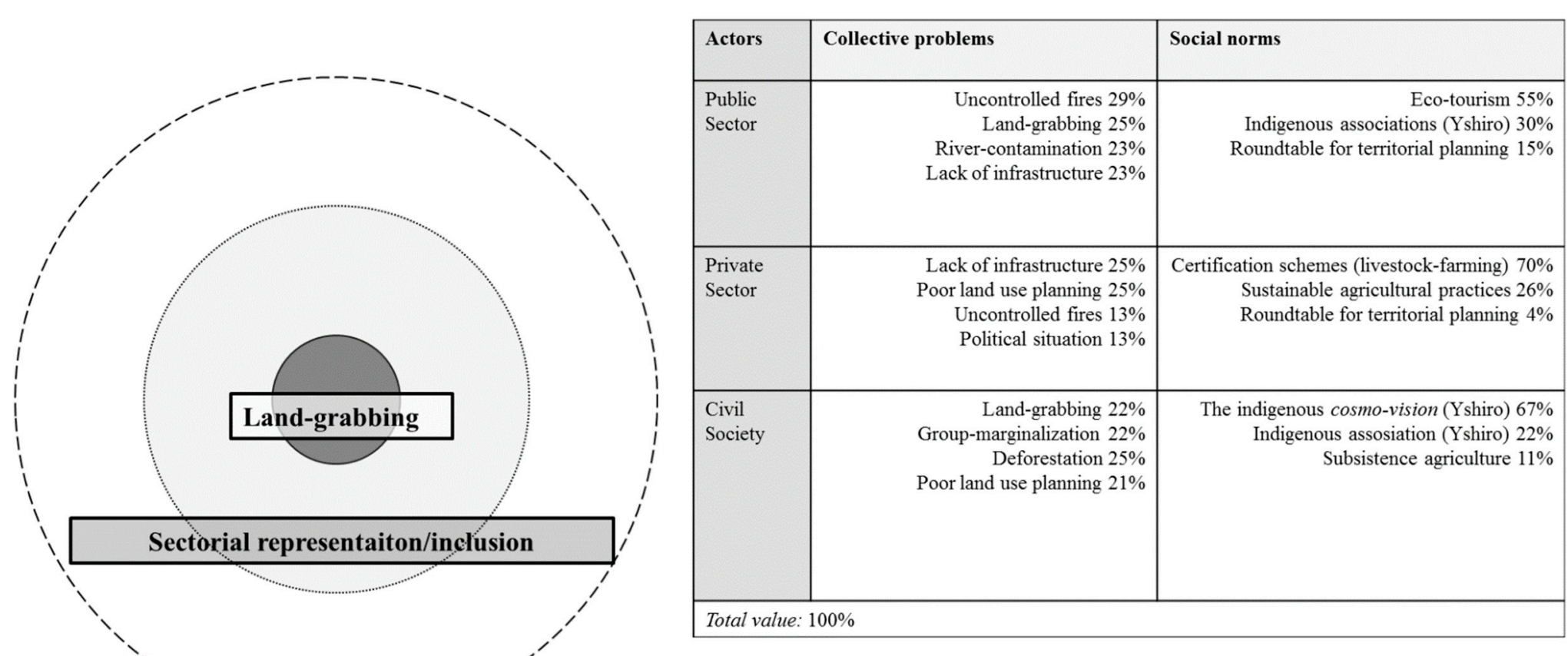

Figure 8. Paraguay—Results of the GAF (ranking). Source: [81]. 


\section{Discussion}

Relations between political, economic, and social institutions dealing with environmental issues, challenges, and changes fall under the IAD framework (Figure 9). Issues around the use and management of natural resources are regarded as political ecological problems [86,87]. The following discussion tackles the complexity of economic and political centralization, the role of governments, and social exclusion as causes of weak governance.

\section{Adapted IAD framework for discussion}

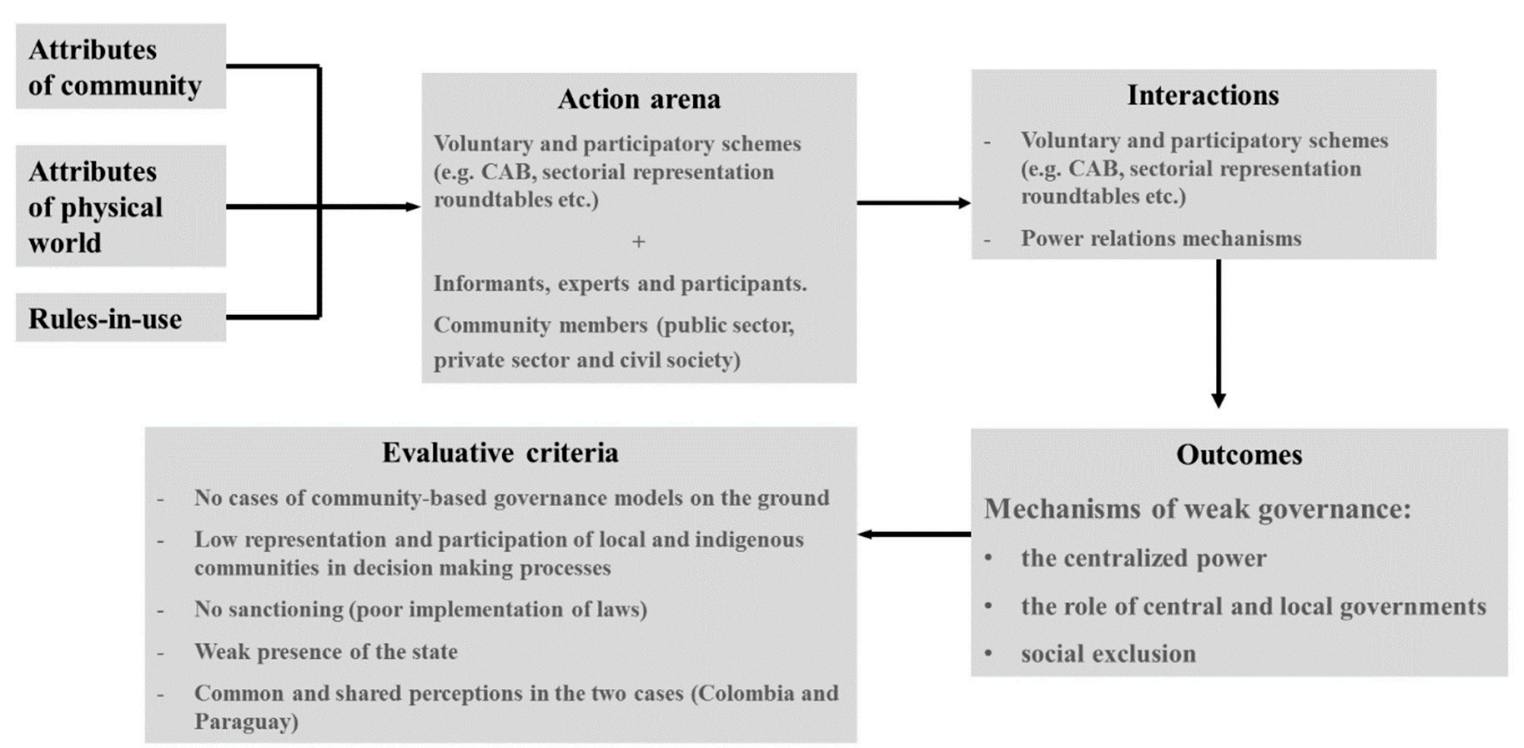

Figure 9. Adapted IAD framework for discussion. Source: [63].

\subsection{Comparative Analysis: Governance in Colombia and Paraguay}

In both Colombia and Paraguay, the productive sector (extractive activities, agroindustry, etc.) is predominantly considered responsible for the misuse (Colombia) and over-exploitation (Paraguay) of natural resources (Figures 5 and 7). All groups involved, directly or indirectly, in the use and management of natural resources (e.g., private and productive sector, public sector, rural and indigenous communities, etc.) are related hierarchically, ultimately with the productive sector (e.g., often represented by financial and foreign investments) on top, the main ruler of the game [29]. The exploitation of hydrocarbons, monoculture expansion (oil and rice in Colombia), and land grabbing (Paraguay) are the main collective problems addressed in the context of weak governance (Figures 6 and 8). These occur due to the present neoliberal economic model under which productive sectors use their political and economic power to pursue market-driven interests [88].

Thus, this accumulation mode (often unregulated) of natural resources for international export might be the main constraint to sustainable alternatives. Regional literature suggests extractive interventions are an increasingly important development strategy and policy throughout Latin America [42,54,55,89]. Economists and analysts argue how "extractivism" is an evolution of the development path chosen by most South American countries, prioritizing extraction and exploitation of natural wealth for global markets [55]. In both Colombia and Paraguay, land distribution and land planning are strategic means for power relations and negotiations. Alongside neoliberal perspectives, extractivism prefers external markets to local ones; it encourages wealth concentration, marginalizing equitable distribution of the same wealth [55]. In one market-oriented extractive economic model, within the political and productive-sector agenda, natural resources are managed under a hierarchical structure where power-relations and interferences occur [88]. Historically, socio-ecological and distributive conflicts related to extractivism have been occurring for centuries in both rural Colombia and 
Paraguay [37]. Equity in the distribution of goods and services is not an option when the 'rules of the game' are designed by those institutions, whether formal or informal, holding greater economic assets and political influence. Instead, literature on good governance of natural resources reaffirms the importance of wide involvement, representation of diverse interests, legitimacy, and responsiveness to both local customs and formal legal systems [90].

\subsubsection{Centralization}

In addition, the wide expanses and remoteness of the areas are key obstacles inhibiting transparency measures (e.g., monitoring) and formal boundaries (e.g., law enforcement and control). Nevertheless, policy reforms over land use and land distribution in both Colombia and Paraguay show, not just trends toward privatization, but also the delegation of service provisions to the private sector and, at times, civil society actors [57]. The results reflect this, although the presence of the state, even in formal forms of delegation of action and powers, is not perceived as a reality; instead it generates informal patterns regarding the use and management of natural resources. Within formal institutions and settings, centralized and top-down models, supported by neoliberal and extractive systems, exacerbate the marginalization of local governments and institutions (e.g., lack of financial and human support, etc.). In such contexts, alternatives ensuring public service provision by community members, while demanding support from the state to facilitate the conditions for such effort, are compromised [56,62]. Both the lack of trust in and within public institutions and the lack of standards for democratic governance may negatively affect the fairness of decision making processes [90]. Thus, the mechanism of power centralization and authority in the hands of private economic actors, especially in terms of economic impacts, underlies weak governance [91].

\subsubsection{Role of Governments}

Under the NIE lens, property rights models are economic property rights, not legal property rights (enforced by the government). These rights aim to consume, either directly or indirectly through exchange or transactions, the goods and service of the resources by including rights for resource usage, rights to earn income from it, and rights to transfer ownership rights [92,93]. Economic property rights inherently represent institutions that benefit from the weak resource management of public institutions and, particularly, the unclear structures of ownership, monitoring, and control (e.g., law compliance etc.). These can foster informal institutions, such as corruption (Colombia) and impunity (Paraguay) that cause social and environmental conflicts. Under this scenario, natural resource struggles require a clear definition of group boundaries to be solved [94]. However, the nebulousness of property rights, due to different circumstances (e.g., armed conflict, foreign interferences, and financial speculations, etc.), is disastrous for natural resources [55]. As these cases show, unsuccessful efforts to govern and manage natural resources appear linked to hierarchical organizational structures. Decision-making processes and accountability can represent a major threat to democratic processes when it excludes local perspectives, thus increasing institutional tensions throughout [90], (Hare et al., 2018). Where the main user obtains control through force (e.g., economic, rooted into informal institutions, etc.), due to the other groups' inability or impossibility (e.g., public institutions, local and rural communities etc.) to govern natural resources, conflicts over the inequity of products or raw materials from natural resources arise [94]. Thus, the same resources are exposed and subject to misuse and (unsustainable) exploitation unless formal or informal limits are enforced [68]. As Stebek (2011) notes, there is no automatic association of natural resources with any property regime type [94]. Further, common property arrangements are essentially share-contracts [92] and, as such, face problems of opportunistic behavior and moral hazard. Without solid formal institutions present on the ground, as well as a shift away from neo-liberal and extractivist approaches, the role of central and local governments (how it functions) causes weak governance. By prioritizing the interests of economic powers over those of rural communities, governments are unwilling or unable to fully assume their responsibilities, especially with regard to reducing inequalities over the use and management of natural resources [95]. 


\subsubsection{Social Exclusion}

Further, from the community perspective, rural and indigenous groups are typically left behind and marginalized (see "evaluative criteria", Figure 9). Thus, the voices of the most vulnerable citizens are unheard when there are conflicts balancing land-use between the exploitation and provision of natural resources with local needs and conditions. Hence, social inclusion in managing natural resources and creating better models for governance is a mirage and, in most cases, viewed through the prism of informal or illegal economic exchange and voter-politician relations. Nevertheless, in order to facilitate and encourage inclusive and collective actions for common purposes, local group members suggest a stronger focus on those assets intrinsic to social relations, such as trust and networks of association representing local needs and groups within the 'action arena' (e.g., CAB or indigenous associations) [65]. Even if public trust practices vary across cultures and over time, and when local laws and norms do not directly embody specific standards for democratic governance, they are likely to be situated within governance systems in which good governance applies at some level [90]. In the social sciences, there is a vast amount of literature on pluralistic approaches in the exercise of politics and governance [63,96-101]. For instance, a higher degree of voluntary participation in movements and association results in better networks of relationships among communities. Likewise, greater inclusion in problem-solving strategies alongside the government allows society to function more efficiently. Smaller community networks increase the need to rely on imposing and authoritative controls, either political or economic [101]. Hence, based on our Colombian and Paraguayan cases, social exclusion is an additional mechanism of weak governance [102]. As Beall (2002) argues, "From a neoliberal perspective, social exclusion can be seen as an unfortunate but inevitable side effect of global economic realignment", [103] (pp. 43-44).

In both regions, hierarchical and market-based structures prevail over community management. However, community management of natural resources between government actors and local resource users is promising for conservation and local development $[104,105]$. While this is critical in both cases, the underlying tenure rights and land concentration only allows for changes in management if the government initiates the changes.

As for future recommendations, we suggest:

- In-depth analysis of land-use using social representation studies that leverage our results when including the mechanisms of weak governance discussed;

- Central and local institutions in Colombia and Paraguay should formulate cross-cutting groups to manage natural resources, building capacity for inclusive forms of governance (principles and frameworks through decentralization of functions and power to locals);

- Civil society should implement projects focusing on need-based development for better management of natural resources as well as poverty alleviation and the reduction of socio-economic inequality.

\subsection{Limitations}

There are limitations to these results. (1) In the online survey (Phase B) the sample size might not be sufficient (32 respondents) and does not exhaustively cover private sector expertise. The 13 experts who did not complete the survey could have added specific knowledge about agricultural and extractive industries. However, it was challenging to find regional experts willing to participate to our research. (2) In the GAF survey, the research suffers from the quality of the sample composition. Within the private and productive sectors, those who participated belonged to the subsistence and livestock agricultural sector. None of the participants represented the agricultural or extractive industries (e.g., monoculture, hydrocarbons, etc.); heterogeneity in the results may have resulted. Further, the degree to which the research tends to generalize is limited: By implementing only two of the five GAF analytical tools (Phase B) and by having collected subjective perceptions (Phase C), the replicability of this study may be affected. Thus, the results might not translate or be transferrable to a broader context. However, 
based on our research scope (i.e., perception on mechanisms of weak governance), we present cases where existing research is scarce.

\section{Conclusions}

The grasslands and wetlands of Colombia and Paraguay face weak governance, in both its institutional and community-based contexts. This work hybrid conceptualization provided a synthesis of how top-down hierarchical and market-based systems of community-based and natural resource management negatively affect sustainable development in both study areas. Three mechanisms causing weak governance were identified: the centralized economic and political power, the role of central and local governments, and social exclusion.

These findings should be seen in the light of the following conceptual contributions. First, they underpin the knowledge that weak governance encourages social inequalities and the erosion of local cultures, with destabilizing consequences [91]. Second, they are often in relation to environmental degradation, including in national parks and other protected areas, as well as illegal land grabbing and land tenure speculations. Third, the mechanisms of weak governance may thrive under the following circumstances: (i) where formal laws are complex, incoherent, or outdated; (ii) where informal institutions, such as corruption or impunity, are directly linked to socio-environmental conflicts; (iii) where decision making and budgeting processes are centralized in urban areas, having direct impacts on law enforcement and monitoring at the local level; (iv) where weak property regimes of land tenure, land distribution, and land planning are in place; and (v) where multi-level exclusion (social status, gender, ethnicity, education, etc.) exists.

Instead, good governance should ensure human and land rights and protect natural resources, while also promoting socially and economically sustainable development $[58,81,106]$. Therefore, institutional structures supporting arrangements that handle grasslands and wetlands in a sustainable way are needed to protect the ecosystem's social and economic values, especially in rural and marginalized contexts.

Author Contributions: Conceptualization, L.E., M.B. and B.S.; Methodology, M.B.;Validation, S.S.; Formal Analysis, L.E.and M.A.L.; Investigation, L.E.; Resources, S.S.; Data Curation, L.E., M.B., S.S. and B.S.; Writing一Original Draft Preparation, L.E.; Writing-Review \& Editing, L.E., M.B., S.S., B.S. and M.A.L.; Visualization, L.E. and M.A.L.; Supervision, M.B., B.S. and M.A.L.; Project Administration, M.B.; Funding Acquisition, L.E. All authors have read and agreed to the published version of the manuscript.

Funding: This research is funded by a project of the International Climate Initiative (IKI). The Federal Ministry for the Environment, Nature Conservation and Nuclear Safety (BMU) supports this initiative on the basis of a decision adopted by the German Bundestag.

Acknowledgments: Our gratitude goes to the World Wildlife Fund (WWF) offices of Colombia, Paraguay and Germany for providing their expertise. Special thanks to WWF Paraguay Conservation Director Karim Musalem for his support in the field.

Conflicts of Interest: The authors declare no conflict of interest. The funders had no role in the design of the study; in the collection, analyses, or interpretation of data; in the writing of the manuscript, and in the decision to publish the results.

\section{Appendix A}

Table A1. List of institutions involved in the field-based studies (online survey, Phase B).

\begin{tabular}{lll}
\hline \multicolumn{2}{c}{ Colombia } & \multicolumn{2}{c}{ Paraguay } \\
\hline \multirow{2}{*}{ 1. Universidad de los Llanos } & 1. & Green Solutions S.A. \\
\cline { 3 - 3 } & 2. & $\begin{array}{l}\text { Ministry of Agriculture and Livestock-Programa } \\
\text { Nacional Fomento Agropecuario }\end{array}$ \\
\hline \multirow{2}{*}{ 2. Universidad del Rosario } & 3. & Secretary of the Environment-SEAM \\
\cline { 2 - 3 } & 4. & $\begin{array}{l}\text { National Secretariat for Housing and } \\
\text { Habitat-SENAVITAT }\end{array}$ \\
\hline
\end{tabular}


Table A1. Cont.

\begin{tabular}{|c|c|c|}
\hline & Colombia & Paraguay \\
\hline 3. & Universidad de los Andes & $\begin{array}{l}\text { 5. Technical Secretariat for Economic and Social } \\
\text { Development Planning-STP }\end{array}$ \\
\hline 4. & Universidad de los Andes & Forestry Institute-INFONA \\
\hline 5. & Universidad Nacional de Colombia & $\begin{array}{l}\text { Minister of Foreign Affairs-Coordination of the } \\
\text { Environmental Affairs Unit }\end{array}$ \\
\hline 6. & International left for Tropical Agriculture-CIAT & Paraguay Selvaje \\
\hline 7. & $\begin{array}{l}\text { Fundación Centro para la Investigación en Sistemas } \\
\text { Sostenibles de Producción Agropecuaria-CIPAV }\end{array}$ & Centro de Pesquisa do Pantanal- $\mathrm{CPP}$ \\
\hline 8. & Wildlife Conservation Society Colombia-WCS & Solidaridad Paraguay \\
\hline 9. & Corporinoquia Colombia & $\begin{array}{l}\text { Fundación para el Desarrollo Sustentable en las } \\
\text { Américas del Norte y del Sur }\end{array}$ \\
\hline 10. & $\begin{array}{l}\text { Corporación Para El Desarrollo Sostenible Del Área } \\
\text { De Manejo Especial De La Macarena_Cormacarena }\end{array}$ & Paraguay Magazine \\
\hline 11. & $\begin{array}{l}\text { Organización Internacional para las Migraciones } \\
\text { (OIM) }\end{array}$ & $\begin{array}{l}\text { Program of Support For Volunteers In } \\
\text { Protected Areas-PAVAP }\end{array}$ \\
\hline 12. & El Orinoco Se Adapta & National University of Asunción \\
\hline 13. & World Wildlife Fund-WWF Colombia & Guyra Paraguay \\
\hline 14. & $\begin{array}{l}\text { Instituto de Hidrología, Meteorología y } \\
\text { Estudios Ambientales-IDEAM }\end{array}$ & Wildlife Conservation Society Paraguay_WCS \\
\hline 15. & Asociación de apoyo al Desarrollo-APOYAR & World Wildlife Fund-WWF Paraguay \\
\hline
\end{tabular}

\section{References}

1. Suttie, J.M.; Reynolds, S.G.; Batello, C. (Eds.) Grasslands of the World; FAO: Rome, Italy, 2005.

2. Ridder, R.M. Global Forest Resources Assessment 2010: Options and Recommendations for a Global Remote Sensing Survey of Forests; FAO For. Resource Assessement Programme Working Paper 141; FAO: Rome, Italy, 2007.

3. Conant, R.T. Challenges and Opportunities for Carbon Sequestration in Grassland Systems; FAO: Rome, Italy, 2010.

4. Rippstein, G. Agroecología y Biodiversidad de las Sabanas en los Llanos Orientales de Colombia; Ciat: Cali, Colombia, 2001.

5. Blydenstein, J. Tropical Savanna Vegetation of the Llanos of Colombia. Ecology 1967, 48, 1-15. [CrossRef]

6. Swarts, F.A. The Pantanal of Brazil, Bolivia and Paraguay: Selected Discourses on the World's Largest Remaining Wetland System; Paragon House: St. Paul, MN, USA, 2000.

7. Guyra Paraguay. Informe de Deforestación Marzo 2017; Guyra Paraguay: Asuncion, Paraguay, 2017.

8. Pollock, M.M.; Naiman, R.J.; Hanley, T.A. Plant species richness in riparian wetlands-A test of biodiversity theory. Ecology 1998, 79, 94-105.

9. Mitsch, W.J.; Zhang, L.; Waletzko, E.; Bernal, B. Validation of the ecosystem services of created wetlands: Two decades of plant succession, nutrient retention, and carbon sequestration in experimental riverine marshes. Ecol. Eng. 2014, 72, 11-24. [CrossRef]

10. Maltby, E.; Acreman, M.C. Ecosystem services of wetlands: Pathfinder for a new paradigm. Hydrol. Sci. J. 2011, 56, 1341-1359. [CrossRef]

11. O'Mara, F.P. The role of grasslands in food security and climate change. Ann. Bot. 2012, 110, $1263-1270$. [CrossRef]

12. Mitsch, W.J.; Bernal, B.; Hernandez, M.E. Ecosystem services of wetlands. Int. J. Biodivers. Sci. Ecosyst. Serv. Manag. 2015, 11,1-4. [CrossRef]

13. Ishwaran, N.; Clüsener-Godt, M. Los Sitios UNESCO en Iberoamérica para Medio Ambiente y Cultura Como Escenarios del Desarrollo Sostenible. Hacia una Cultura de la Conservación de la Diversidad Biológica, Zaragoza, SEA, Conabio, Conanp, Conacyt, Inecol; Unesco-MAB, Ministerio de Medio Ambiente-Gobierno de España: Zaragoza, Spain, 2007. 
14. Salcedo, H.R.; Barrera, A.C. Sobre los procesos de enseñanza-aprendizaje en el legado de los cantos de trabajo del llano, patrimonio cultural inmaterial de la Orinoquia. Cultura Lenguaje Representación 2019, 21, 133-156. [CrossRef]

15. Anderson, R.; Rockel, M. Economic Valuation of Wetlands: Discussion Paper n. 065; American Petroleum Institute: Washington, DC, USA, 1991.

16. Barbier, E.B.; Acreman, M.; Knowler, D. Valoración Económica de los Humedales: Guía para Decisores y Planificadores; Gland: Oficina de la Convención de Ramsar: Cambridge, UK, 1997.

17. Woodward, R.T.; Wui, Y.-S. The economic value of wetland services: A meta-analysis. Ecol. Econ. 2001, 37, 257-270. [CrossRef]

18. Brander, L.M.; Florax, R.J.G.M.; Vermaat, J. The Empirics of Wetland Valuation: A Comprehensive Summary and a Meta-Analysis of the Literature. Environ. Resour. Econ. 2006, 33, 223-250. [CrossRef]

19. Plummer, M.L. Assessing benefit transfer for the valuation of ecosystem services. Front. Ecol. Environ. 2009, 7, 38-45. [CrossRef]

20. Heidenreich, B. What Are Global Temperate Grasslands Worth? A Case for Their Protection IUCN: Gland, Switzerland, 2009.

21. Mereles, M.F. Los Humedales del Paraguay: Principales Tipos de Vegetación. In Los humedales de Paraguay; Salas, D.A., Mereles, M.F., Yanosky, A., Eds.; Comité Nacional de Humedales del Paraguay: Asunción, Paraguay, 2004; pp. 67-87.

22. Folke, C. The Societal Value of Wetland Life-Support. Linking the Natural Environment and the Economy: Essays from the Eco-Eco Group; Springer: Dordrecht, The Netherlands, 1991; pp. 41-171.

23. Adams, W.M. Indigenous use of wetlands and sustainable development in West Africa. Geogr. J. 1993, 159, 209-218. [CrossRef]

24. Mejía, C.A.C. Palabra de agua: Relatos ancestrales muiscas para la recuperación ecológica del humedal Tibabuyes. InvestigiumIre Ciencias Sociales Humanas 2013, 4, 122-132.

25. Mosquera, S.L.; Nieto, O.; Tapia, C. Humedales para la Gente: Visiones desde lo Local; Instituto de Investigación de Recursos Biológicos Alexander von Humboldt: Bogotá, Colombia, 2015; p. 98.

26. Chaikumbung, M.; Doucouliagos, H.; Scarborough, H. Institutions, Culture, and Wetland Values. Ecol. Econ. 2019, 157, 195-204. [CrossRef]

27. Ioris, A.A.R.; Irigaray, C.T.; Girard, P. Institutional responses to climate change: Opportunities and barriers for adaptation in the Pantanal and the Upper Paraguay River Basin. Clim. Chang. 2014, 127, 139-151. [CrossRef]

28. Schulz, C.; Whitney, B.S.; Rossetto, O.C.; Neves, D.M.; Crabb, L.A.H.; Oliveira, E.C.; Lima, P.L.T.; Afzal, M.; Laing, A.; De Souza, L.C.; et al. Physical, ecological and human dimensions of environmental change in Brazil's Pantanal wetland: Synthesis and research agenda. Sci. Total Environ. 2019, 687, 1011-1027. [CrossRef] [PubMed]

29. Ioris, A.A.R. Rethinking Brazil's Pantanal Wetland. J. Environ. Dev. 2013, 22, 239-260. [CrossRef]

30. Peñuela, L. Sabana Inundable y Ganadería, Opción Productiva de Conservación en la Orinoquia; No. LC-0835; Fundación Natura: Bogota, Colombia, 2014.

31. Soto, B.F.; Gómez, S. Dinámicas del Mercado de la Tierra en América Latina y el Caribe: Concentración y Extranjerización; FAO: Rome, Italy, 2012.

32. Soto, B.F.; Gómez, S. (Eds.) Reflexiones sobre la Concentración y Extranjerización de la Tierra en América Latina y el Caribe; FAO: Rome, Italy, 2013.

33. Rincón, S.; Flantua, S. Identifying Highly Biodiverse Savannas Based on the European Union Renewable Energy Directive (SuLu Map): Conceptual Background and Technical Guidance; WWF: Asuncion, Paraguay, 2014.

34. World Wildlife Fund (WWF). Social, Economic and Environmental Analysis of Soybean and Meat Production in Paraguay; WWF: Asunción, Paraguay, 2016.

35. Martínez-Alier, J. Los conflictos ecológico-distributivos y los indicadores de sustentabilidad. Revibec: Revista Red Iberoamericana Economía Ecológica 2004, 1, 21-30.

36. Blaser, M. The Threat of the Yrmo: The Political Ontology of a Sustainable Hunting Program. Am. Anthr. 2009, 111, 10-20. [CrossRef]

37. Acuña, R.M. The politics of extractive governance: Indigenous peoples and socio-environmental conflicts. Extr. Ind. Soc. 2015, 2, 85-92. [CrossRef]

38. Guereña, A.; Villagra, V.L. Yvy Jára: Los Dueños de la Tierra en Paraguay; Oxfam: Asunción, Paraguay, 2016. 
39. Hincapié, S. Extractivismo, consultas populares y derechos políticos ¿el renacimiento de la democracia local en Colombia? Reflexión Política 2017, 19, 86-99. [CrossRef]

40. Duarte, O.J. Desarrollo, Extractivismo Petrolero y Transformaciones Socioterritoriales en el Municipio de Aguazul, Casanare (Colombia) 1990-2015. Master's Thesis, Universidad Nacional de Colombia, Sede Bogotá, Colombia, 2018.

41. Eufemia, L.; Bonatti, M.; Sieber, S. Synthesis of Environmental Research Knowledge: The Case of Paraguayan Pantanal Tropical Wetlands. Sustain. Agric. Res. 2018, 7, 125-133. [CrossRef]

42. Safford, T.G. The Political-Technical Divide and Collaborative Management in Brazil's Taquari Basin. J. Environ. Dev. 2010, 19, 68-90. [CrossRef]

43. Garcia, M.M.; Bodin, Ö. Participatory Water Basin Councils in Peru and Brazil: Expert discourses as means and barriers to inclusion. Glob. Environ. Chang. 2019, 55, 139-148. [CrossRef]

44. Ardila Barbosa, W.Y. Impactos de la Industria Petrolera en el Medio Ambiente-Upstreamí. Ph.D. Thesis, Universidad Industrial de Santander, Escuela de Ingenieria de Petróleos, Bogota, Colombia, 2014.

45. Vatn, A. An institutional analysis of payments for environmental services. Ecol. Econ. 2010, 69, 1245-1252. [CrossRef]

46. Larson, A.M.; Soto, F. Decentralization of natural resource governance regimes. Annu. Rev. Environ. Resour. 2008, 33, 213-239. [CrossRef]

47. Lockwood, M.; Davidson, J.; Curtis, A.; Stratford, E.; Griffith, R. Governance Principles for Natural Resource Management. Soc. Nat. Resour. 2010, 23, 986-1001. [CrossRef]

48. Halsall, J.; Oberoi, R.; Cook, I.G.; Wankhade, P. Understanding community governance: A global perspective. Int. J. Asian Soc. Sci. 2013, 3, 1112-1127.

49. Quintero López, M.; Fabio, A.; Arbeláez, A. Nature conservation on private land: Natural Reserves of Civil Society in Valle del Cauca. Apuntes Cenes 2016, 35, 17-48. [CrossRef]

50. Blaser, M. Storytelling Globalization from the Chaco and Beyond; Duke University Press: Durham, NC, USA, 2010.

51. Ansell, C.; Torfing, J. Handbook on Theories of Governance; Edward Elgar Publishing: Cheltenham, UK, 2016.

52. De Castro, F. Gobernanza Ambiental en América Latina; Hogenboom, B., Baud, M., Eds.; Clacso: Buenos Aires, Argentina, 2015.

53. Lamont, H. Environmental Governance: The Global Challenge; Island Press: Washington, DC, USA, 1996.

54. Gudynas, E. Diez tesis urgentes sobre el nuevo extractivismo. Extractivismo Política Sociedad 2009, 187, 222-223.

55. Acosta, A. Extractivismo y neoextractivismo: Dos caras de la misma maldición. Más Allá Desarrollo 2011, 1, 83-118.

56. Olivos, Á.R. El concepto de bienes comunes en la obra de Elinor Ostrom. Ecología Política 2013, 45, $116-121$.

57. Zurbriggen, C. Governance a Latin America perspective. Policy Soc. 2014, 33, 345-360. [CrossRef]

58. Palmer, D.; Fricska, S.; Wehrmann, B. Towards Improved Land Governance; Food and Agriculture Organization of the United Nations, United Nations Human Settlements Programme: Rome, Italy, 2009.

59. Rudd, M.A. An institutional framework for designing and monitoring ecosystem-based fisheries management policy experiments. Ecol. Econ. 2004, 48, 109-124. [CrossRef]

60. Ostrom, E. Understanding Institutional Diversity; Princeton University Press: Princeton, NJ, USA, 2005.

61. Clement, F. Analysing decentralised natural resource governance: Proposition for a "politicised" institutional analysis and development framework. Policy Sci. 2010, 43, 129-156. [CrossRef]

62. Clement, F.; Amezaga, J.M. Conceptualising context in institutional reforms of land and natural resource management: The case of Vietnam. Int. J. Commons 2013, 7, 140-163. [CrossRef]

63. Nigussie, Z.; Tsunekawa, A.; Haregeweyn, N.; Adgo, E.; Cochrane, L.; Floquet, A.; Abele, S. Applying Ostrom's institutional analysis and development framework to soil and water conservation activities in north-western Ethiopia. Land Use Policy 2018, 71, 1-10. [CrossRef]

64. Ostrom, E.; Gardner, R.; Walker, J. Rules, Games, and Common-Pool Resources; University of Michigan Library: Ann Arbor, MI, USA, 1994.

65. Ostrom, E. Institutional Rational Choice: An Assessment of the Institutional Analysis and Development Framework. In Theories of the Policy Process, 2nd ed.; Sabatier, P.A., Ed.; Westview Press: Cambridge, MA, USA, 2007; pp. 21-64.

66. Ostrom, E. Background on the Institutional Analysis and Development Framework. Policy Stud. J. 2011, 39, 7-27. [CrossRef] 
67. Ostrom, E. Governing the Commons; Cambridge University Press (CUP): Cambridge, UK, 1990.

68. Ostrom, E. Designing Complexity to Govern Complexity. In Property Rights and the Environment: Social and Ecological Issues; Munasinghe, M., Hanna, S., Eds.; The International Bank for Reconstruction and Development: Washington, DC, USA, 1995; pp. 33-45.

69. Nickson, A. Where Is Local Government Going in Latin America? A Comparative Perspective; Swedish International Centre for Local Democracy Fuente: Stockholm, Sweden, 2016.

70. Saunders, F.P. The promise of common pool resource theory and the reality of commons projects. Int. J. Commons 2014, 8, 636-656. [CrossRef]

71. Hiram, Á.L. El gobierno de los bienes comunes: La evolución de las instituciones de acción colectiva. Región Sociedad 2002, 14, 263-269.

72. Cyert, R.M.; March, J.G. A behavioral theory of the firm. Englewood Cliffs N. J. 1963, 2, 169-187.

73. Herbert, S.A. Theories of bounded rationality. Decis. Org. 1972, 1, 161-176.

74. Eaton, W.O. The Economic Institutions of Capitalism: Firms, Markets, Relational Contracting; Free Press: New York, NY, USA, 1985.

75. Williamson, O.E. The Mechanisms of Governance; Oxford University Press: Oxford, UK, 1996.

76. Petri, O. Principles of Institutional Economics-with Applications to Cooperative Enterprises; Working Papers 56; Departments of Economics, Helsinki University: Helsinki, Finland, 2009.

77. Lee, A.J.; North, D.; Eggerttson, T. (Eds.) Empirical Studies in Institutional Change; Cambridge University Press: Cambridge, UK, 1996.

78. North, D.C. Introduction to Understanding the Process of Economic Change; Princeton University Press: Princeton, NJ, USA, 2005.

79. Hufty, M. Investigating Policy Processess: The Governance Analytical Framework (GAF). In Research for Sustainable Development: Foundations, Experiences, and Perspectives; Wiesmann, U., Huni, H., Eds.; North-South/Geographica: Bern, Switzerland, 2012; Volume 1, pp. 403-424.

80. Biernacki, P.; Waldorf, D. Snowball Sampling: Problems and Techniques of Chain Referral Sampling. Sociol. Methods Res. 1981, 10, 141-163. [CrossRef]

81. Iribarnegaray, M.A.; Seghezzo, L. Governance, Sustainability and Decision Making in Water and Sanitation Management Systems. Sustainability 2012, 4, 2922-2945. [CrossRef]

82. Abe, J.; Brown, B.; Ajao, E.A.; Donkor, S. Local to regional polycentric levels of governance of the Guinea Current Large Marine Ecosystem. Environ. Dev. 2016, 17, 287-295. [CrossRef]

83. Montoya, M.A.; Chauvet, M. Technical standards in nanotechnology as an instrument of subordinated governance: Mexico case study. J. Responsible Innov. 2016, 3, 1-34.

84. Clifford, G. Thick Description: Toward an Interpretive Theory of Culture. The Interpretation of Cultures: Selected Essays; Basic: New York, NY, USA, 1973; pp. 3-30.

85. Malinowski, B. Argonauts of the Western Pacific: An Account of Native Enterprise and Adventure in the Archipelagoes of Melanesian New Guinea [1922/1994]; Routledge: London, UK, 2013.

86. Watts, M. Political Ecology. In A Companion to Economic Geography; Peck, J., Sheppard, E., Barnes, T., Eds.; Blackwell Publishing: Malden, MA, USA, 2000; pp. 257-274.

87. Robbins, P. Political Ecology: A critical Introduction; John Wiley \& Sons: Hoboken, NJ, USA, 2011; Volume 16.

88. Kay, C. La transformación neoliberal del mundo rural: Procesos de concentración de la tierra y del capital y la intensificación de la precariedad del trabajo. Revista Latinoamericana Estudios Rurales 2016, 1, 1-26.

89. Brand, U.; Dietz, K.; Lang, M. Neo-Extractivism in Latin America-One side of a new phase of global capitalist dynamics. Ciencia Política 2016, 11, 125-159. [CrossRef]

90. Hare, D.; Forstchen, A.B.; Smith, C.A.; Decker, D.J. Developing Governance Principles for Public Natural Resources. Soc. Nat. Resour. 2017, 31, 382-388. [CrossRef]

91. Vargas, J.G. Teoría de la acción colectiva, sociedad civil y los nuevos movimientos sociales en las nuevas formas de gobernabilidad en Latinoamérica. Espacio Abierto 2003, 12, 523-537.

92. Eggertsson, T. Economic Behavior and Institutions; Cambridge University Press: Cambridge, UK, 1990.

93. Barzel, Y. Economic Analysis of Property Rights; Cambridge University Press: Cambridge, UK, 1997.

94. Stebek, E. Conceptual Foundations of Property Rights: Rethinking De Facto Rural Open Access to Common-Pool Resources in Ethiopia. Mizan Law Rev. 2011, 5, 1-40. [CrossRef]

95. Shah, S.A. Corruption and Decentralized Public Governance; World Bank: Washington, DC, USA, 2006.

96. Loury, G. A dynamic theory of racial income differences. Women Minor. Empl. Discrim. 1977, 153, 86-153. 
97. Putnam, R.D.; Leonardi, R.; Nanetti, R.Y. Making Democracy Work: Civic Traditions in Modern Italy; Princeton University Press: Princeton, NJ, USA, 1994.

98. Smith, T.W. Factors Relating to Misanthropy in Contemporary American Society. Soc. Sci. Res. 1997, 26, 170-196. [CrossRef]

99. Smith, M.H.; Beaulieu, L.J.; Seraphine, A. Social Capital, Place of Residence, and College Attendance1. Rural. Sociol. 2010, 60, 363-380. [CrossRef]

100. Teachman, J.D.; Paasch, K.; Carver, K. Social Capital and Dropping Out of School Early. J. Marriage Fam. 1996, 58, 773. [CrossRef]

101. Brehm, J.; Rahn, W. Individual-Level Evidence for the Causes and Consequences of Social Capital. Am. J. Pol. Sci. 1997, 41, 999-1023. [CrossRef]

102. Manuel, C.C. Gobernanza y participación ciudadana en las políticas públicas frente al reto del desarrollo. Politica Cultura 2008, 30, 9-37.

103. Beall, J. Globalization and social exclusion in cities: Framing the debate with lessons from Africa and Asia. Environ. Urban. 2002, 14, 41-51. [CrossRef]

104. Carlsson, L.G.; Berkes, F. Co-management: Concepts and methodological implications. J. Environ. Manag. 2005, 75, 65-76. [CrossRef]

105. Fabricius, C.; Folke, C.; Cundill, G.; Schultz, L. Powerless Spectators, Coping Actors, and Adaptive Co-managers: A Synthesis of the Role of Communities in Ecosystem Management. Ecol. Soc. 2007, 12, 1-9. [CrossRef]

106. Willis, E.; da Garman, C.B.C.; Haggard, S. The politics of decentralization in Latin America. Lat. Am. Res. Rev. $1999,34,7-56$.

(C) 2020 by the authors. Licensee MDPI, Basel, Switzerland. This article is an open access article distributed under the terms and conditions of the Creative Commons Attribution (CC BY) license (http://creativecommons.org/licenses/by/4.0/). 